\title{
AFRICAN METAPHORS FOR GOD: MALE OR FEMALE?
}

\author{
Nisbert Taisekwa Taringa \\ Department of Religious Studies, \\ Classics and Philosophy \\ University of Zimbabwe
}

\begin{abstract}
This paper investigates the extent of sexism in the African concept of God with special reference to the Shona of Zimbabwe. Much of the discussion about African theology tends to present African concepts of God in the context of western Christian theology which emphasises the male image of God and therefore becomes sexist. This approach fails to enhance the authority of women in the sphere of religion and society. Through investigating Shona metaphors for God I argue that African concepts of God are sui generis. They are much less sexist than what African Christian theology presents. The concept of God among the Shona may be expressed as: "Thou art woman, Thou art man". The paper begins by stating the problem and then analyse the following metaphors for God: Mwari/Mhandara, Mbuya/Sekuru, Muvumbi/Muvumbapasi/Muhari, Musiki/Musikavanhu, Dziva/ Dzivaguru/Chidziva Chopo, Runji, Sororezhou and Wokumusoro.
\end{abstract}

\section{Introduction}

African Christian theological reflections have often been carried out in the context of "The exclusively male image of God in the Judeo-Christian tradition" (Porter 1993:487). This has not gone down well with feminist theologians who argue that the male image of God "originates in the experience of alienation from this male image of God experienced by feminist women" (Porter 1993:487). Theological reflections emphasising the male image of God only are therefore a problem for contemporary theology. It is understood as an ideological bias that reflect the sociology of patriarchal societies; that is those societies dominated by male property holding heads of families. Porter (1993) captures this problem well:

What this means quite simply is the following. When God is projected in the image of one sex, rather than both sexes, and in the image of the ruling class of this sex, then this class is seen as consisting in the ones who posses the image of God primarily. Women are regarded as relating to God secondarily and through inclusion in the male as their head.

This means that the male image of God dictates a certain structure for the relationship between the divine and the human. God addresses directly only the patriarchal ruling class. All other groups - women, children, slaves - are addressed by God only indirectly and through the mediation of the patriarchal class. This is also the picture we can infer from Paul in 1Corinthians 2:3,7:

But I want you to understand that the head of every man is Christ, the head of a woman is her husband, and the head of Christ is God ... for a man ought not to cover his head, since he is the image and glory of God; but the woman is the glory of man.

So the woman is seen as lacking the image of God or a direct relation to God herself and can relate to God only secondarily as mediated through the male (Porter 1993: 488). 
The problem that I subsequently raise in this paper is that, since most African Christian theologians tend to present African concepts of God in the framework of the exclusively male image of God typical of the Judaeo-Christian tradition, the feminine image of God in Africa in general, and among the Shona in particular, is suppressed in patriarchal theology. Recognising this fundamentally ideological nature of the male-dominant image of God, I seek to demonstrate that the male image of God among the Shona is never the whole story. God is not always described as a male, there are cases where God is described as a female. This occurs in the metaphors that the Shona use for God. The second part of the paper therefore examines the suppressed feminine image of God. This is in contrast to African theologians such as John S Mbiti who use African metaphors for God to argue that:

The missionaries who introduced the gospel to Africa in the past 200 years did not bring

God to our continent. Instead God brought them. They proclaimed the name of Jesus

Christ, but they used the names of God who was and is already known by African peoples... These were not empty names. They were the names of one and the same God the creator of the world, the father of our lord Jesus Christ (Paris 1995:29).

It is from this point of departure that most African Christian theologians see the supreme deity as male. In the above citation, the African God is the same as the Christian God who is regarded as the father of our Lord Jesus Christ and not as mother of our Lord Jesus Christ. By contrast, I argue that the Shona concept of God is not altogether masculine. In some of the metaphors used to depict the image of God as male there is a parallel feminine image of God which is often suppressed. Let us consider the first metaphor in which God is regarded as Mwari.

\section{God as Mwari/Mhandara}

Mwari is the most common name for God among the Shona. There are several theories regarding the etymology of the name Mwari. One of the theories gives a concept of God which is as sexist as the concepts of God of religions like Judaism, Christianity and Islam. According to this theory, Mwari is thought to have been derived from the Arabic Allah. This rests on the assumption that there is an interchangeability of ' $r$ ' and ' $I$ ' in central African languages. This gives a possibility of " $m u$ " becoming " $m w$ " " as in the case of mwana (child). We therefore need to concede with Van der Merwe (1957:42) who argues that Mwari may have come from Muari or Muali.

The above analysis has been used as a basis for portraying the Shona God as a male just like the Judeo-Christian God. The argument is that Shona grammar forbids joining syllables with two vowels following each other in certain cases. The rule for morphophonemic change results in a case where we drop " $u$ " from the prefix " $m u-$ " and substitute it with " $w$-" so that the prefix " $m u-"$ is identified as " $m w-$ " and therefore $m u$ - + ari gives us Mwari. When you refer to the one who claims to be or the one who claims that "I am", i.e., "ari", the rule requires that the person be called Mwari (Kurasha: 1999:204). The Shona God is identified as male with the Judeo-Christian God who said to Moses: "I am who I am." This is why most works which refer to the Shona God as Mwari use the gender specific pronoun He. Yet there is a feminine aspect to Mwari as a Shona metaphor for God.

Mwari exists in the closest relationship with the female. The use of the word Mwari in the context of female initiation is marked among the eastern and the southern Bantu groups. In this context the word Mwari is used to mean a female initiate (Ranger 1974: 7). That is a girl undergoing initiation. Among the Shona and in Mutare in particular the word Mwari and Mhandara (a girl who has reached puberty) may be used interchangeably. Ranger (1974: 8) captures this aptly: 
The usage has been recorded, indeed, in a great belt of territory flanking the western and central Shona people to the east, like the Barwe and the people of Goromonzi, have marginal rites for women, and in Manicaland we are told that the words Mwari and Mhandara are used interchangeably.

In current African Christian theological reflections, however, we note that this female image of God is suppressed. Mwari is depicted using male images and is therefore regarded as a male High God.

\section{God as Mbuya}

In fact, we need to realise that there are other metaphors which clearly depict the female aspect of God among the Shona. God is like Mbuya (grandmother). One of the oldest Shona tribes, the VaHera sometimes substitutes Mbuya for Mwari when they refer to Mwari's powers of creation and fertility. Despite this observation the powers of creation and fertility are in theological discourses associated with a male God. After noting that the VaHera use the metaphor Mbuya for God, Van der Merwe (1957: 44) refers to "His powers of creation and fertility" and thereby suppresses the female aspect of God. Since the possessive pronoun His is used with God as Mbuya this suppresses the idea of God as female among the Shona.

\section{God as Muvumbapasi}

The female image of God is also reflected in the Shona metaphor for God as muvumbapasi (moulder or fashioner of things). When we discuss this aspect of God in theology we need to be aware that, among the Shona, kuumba in the sense of moulding clay pots is traditionally done by women. Women are the ones who mould and fashion clay-pots (hari). In Shona Christian theological discourse the female aspect is suppressed by the use of the pronoun "he": if God is known as muvumbi it is still assumed that He is the moulder. Why is it not said that She is the moulder? The reason may be that this was mainly a trade associated with Shona women. If we consider Muvumbapasi (founder of the land), we may realise that the world was created through Kuumba an activity associated with women.

\section{God as Muhari}

Furthermore, the metaphor Mwari is sometimes thought to have been derived from Muhari (in the clay-pot). Hari symbolises the womb and therefore women are associated with kuumba. Stillborn children are first put in a hari before they are buried. This symbolises putting them back into the womb and becomes a guarantee for future births. Therefore the metaphor of God as muumbi clearly reflects the female image of God among the Shona.

\section{God as Musikavanhu}

Another popular metaphor used for God among the Shona is Musikavanhu. This metaphor reveals that God is both male and female. Among the Shona kusika was associated with kindling a fire using two sticks. One of the sticks has a hole in it, in which grass was put and the other one (musika) was twisted in the hole until heat and therefore fire is created. Such fire-making tools symbolise the male and female organs. So, for the Shona, when married people engage in sex they are involved in kusika - that is - in creating people. Obviously this involves a male and a female. As the sticks are united, so man and women are united in a process during which new life is created. Kusika means to create. This is the origin of the word musika and therefore musikavanhu. However, the female aspect is 
suppressed through a theological emphasis on the male (the twisted stick/male sexual organs), so that musika and therefore God as musikavanhu is usually depicted as male.

\section{God as Dziva/Dzivaguru/Chidziva chopo}

The female image of God is also suppressed in metaphors which depict God as Dziva/ Dzivaguru and chidziva chopo. These words refer to a great pool and the little pool that is typically adjacent to it (Thorpe 1991:55). Thorpe acknowledges that some Shona names represent the female aspect of Mwari (God) but does not elaborate on this aspect. One of the names that he does mention is Dziva. He writes: "The names Dziva, Mbuya (grandmother) and Zendere, for example, represent the female aspect of Mwari" (Thorpe 1991: 55).

The metaphors Dziva/Dzivaguru/chidziva chopo associate God with water. Symbolically we may regard water as the universal mother who is the source of all life. Waters is the foundation of the whole world. So, among the Shona, God as Dziva/Dzivaguru/ Chidziva chopo can be thought of as feminine in the sense that these metaphors relate God to water and therefore symbolically to the "universal mother", the source of all things in which all potentialities are contained, and in which all seeds thrive (Eliade 1958).

\section{God as Runji}

The Shona God as mother is also depicted in the metaphor Runji. This Shona word means needle. The full name is:

Runji rusingapfumi nguo, rwaivetera kupfuma pasi (the needle which does not sew cloth but has to sew beneath) (Van der Merwe 1974: 43).

This is symbolised by lightning which has the function of sewing heaven and earth together. The Shona therefore talk of a female emissary of Mwari (God) who is called Mbuya waRunji. Among the Shona kusona (sewing) is a trade traditionally associated with women. In fact, every Shona women is expected to be able to sew. Runji is therefore a female image of God that relate to the experiences of Shona women.

\section{God as Sororezhou/Wokumusoro}

There are other metaphors which clearly depicts God as male. These include sororezhou, which means elephant head or father, and wokumusoro which means "he who dwells on high" (Thorpe 1991: 55). Up to this point we can see that the male images of God are never used exclusively among the Shona. This observation has implications for Christian theology in Zimbabwe today.

\section{Implications for Churches/Christian Theology}

The sui generis nature of the African concept of God reflected in the metaphors I analysed above can be a great resource for the church and Christian theology and the wider social order in Zimbabwe. It can work as a basis for developing a less patriarchal theology that unites both sexes in understanding themselves as God-like. This theology may empower both male and female Christians to work together in responding to the political, economic and social challenges facing Zimbabwe today. It appears to be the most appropriate way for contemporary Christian theology to speak about God in a way that is good for both women and men and to be true to the varied African metaphors for God. This makes it possible to respect the integrity, authenticity and dignity of each sex and to think of the complementarities of women and men (Pobee 1994:2) on the basis of the theological idea that "Women as well as men are 
made in the divine image of God and therefore any pattern of discrimination, domination or oppression is contrary to God's justice and sovereignty" (Kanyoro 2002: 17).

It is a pity that the metaphors discussed in this paper have not found their way into making Christian theological reflection less patriarchal/sexist in Zimbabwe. One of the major reasons for this is that the image of a male God inherited from western androcentric Christian theology continues to dominate church discourse in Zimbabwe. This is why even in this case where most Shona people know metaphors about the femaleness of God "it is not always easy for African women to experience God as empowering and liberating in their churches because male clergy in Africa presume to speak of God in exclusively male terms" (Clifford 2001:122).

\section{Conclusion}

The observations made in this paper suggest that the traditional Shona metaphors for God are much less sexist than the way in which God is portrayed in current African Christian Theology. African Christian theological reflections tend to be based on Christianity and Judaism which tend to image God in male terms. I have to acknowledge, however, that it is difficult to estimate the extent of female imagery pertaining to God among the Shona precisely because, like many African languages, the Shona language does not have gender specific pronouns. The use of the pronoun he may have something to do with the languages in which early Christian theology was written. The grammar of such languages influenced theological discourses. The word/noun for God is thus assumed to be masculine. Accordingly, every time a person uses an adjective or a metaphor for God, God is understood to be masculine. This is why even in cases where a Shona metaphor is clearly depicting a female image of God, God is referred to as He. I suggest that God among the Shona should be conceived as: "Thou art man, thou art women". This would mean that the female and male images of God are not be expelled from the way God is named among the Shona. This is a good foundation for formulating a less sexist/patriarchal theology that may empower both male and female in responding to the challenges facing Christian ministry in Zimbabwe today.

\section{BILBIOGRAPHY}

Aschwanden, H 1982. Symbols of Life. Gweru: Mambo Press.

Bourdillon, MFG 1987. The Shona Peoples: An Ethnography of the Contemporary Shona With Special Reference to their Religion. Gweru: Mambo Press.

Clifford, AM 2001. Introducing Feminist Theology. New York: Orbis Books.

Daneel, ML 1970. The God of the Matopo Hills: An Essay on the Mwari Cult in Rhodesia. Leiden: Mouton and Co.

Eliade, M 1958. Patterns in Comparative Religion. New York: The World Publishing Company.

Fortune, G 1973. "Who Was Mwari?" in Roberts RS and Washurst, PR (ed.). Rhodesian History 4, 1-20.

Kanyoro, MRA 2002. Introducing Feminist Cultural Hermenutics: An African Perspective. New York: Sheffield Academic Press. 
Kurasha, JK 1999. "Issues in Shona Religions: A Metaphysical Statement and Dialogical Analysis" in Walsh, TG and Kaufmann, F (eds.). Religion and Social Transformation in Southern Africa. St Paul Minnesota: Paragon House.

Mbiti, JS 1970. Concepts of God in Africa. London: SPCK.

Paris, PJ 1995. The Spirituality of African Peoples. Minneapolis: Fortress Press.

Pobee, JS (ed.) 1994. Culture, Women and Theology. Delhi: ISPCK.

Porter, BF 1993. Religion and Reason: An Anthology. New York: St Martin's Press.

Ranger, TO 1974. "The Meaning of Mwari” in Rhodesian History, Vol 5.

Thorpe, SA 1991. African Traditional Religions: An Introduction. Pretoria: University of South Africa.

Van der Merwe, WJ 1957. "The Shona Idea of God" in NADA. Fort Victoria: Morgenster Mission Press. 